\title{
ARTICLE
}

\section{Relative growth and reproductive parameters in a population of Microphrys bicornutus (Brachyura, Majoidea) from Bocas del Toro, Caribbean Sea, Panama}

Crecimiento relativo y dinámica reproductiva de una población de Microphrys bicornutus

(Brachyura, Majoidea) de Bocas del Toro, Mar Caribe, Panamá

\author{
María Paz Sal-Moyano', Ana Milena Lagos-Tobias², \\ Darryl L. Felder ${ }^{3}$ and Fernando L. Mantelatto ${ }^{4}$
}

\begin{abstract}
${ }^{1}$ Instituto de Investigaciones Marinas y Costeras (IIMyC), Laboratorio de Humedales y Ambientes Costeros, Estación Costera J.J. Nágera, Departamento de Biología, Universidad Nacional de Mar del Plata, Funes 3350, 7600, Mar del Plata, Argentina.paz.salmoyano@gmail.com

${ }^{2}$ Programa de Biología, Universidad del Magdalena, Carrera 32\#22-08, Santa Marta, Colombia. anamilagos@gmail.com ${ }^{3}$ Department of Biology, Laboratory for Crustacean Research, University of Louisiana -Lafayette, Lafayette, LA 705042451, United States. dlf4517@louisiana.edu

${ }^{4}$ Laboratory of Bioecology and Crustacean Systematics, Department of Biology, Faculty of Philosophy, Sciences and Letters at Ribeirão Preto (FFCLRP), University of São Paulo (USP), Postgraduate Program on Comparative Biology, Av. Bandeirantes 3900, 14040-901, Ribeirão Preto, São Paulo, Brazil. flmantel@usp.br
\end{abstract}

\begin{abstract}
Resumen.- Se estudió la estructura de la población, el crecimiento relativo de los caracteres sexuales secundarios de ambos sexos y la fecundidad de las hembras de Microphrys bicornutus de Bocas del Toro, Panamá. Se recolectó manualmente y con red un total de 135 individuos. Las hembras ovígeras midieron 6,5-14,4 mm de ancho de caparazón (AC), las no ovígeras 4,2-16 mm, y los machos 5,9-17,4 mm. El crecimiento relativo del largo del caparazón versus el ancho de caparazón fue isométrico en los machos y alométrico negativo en las hembras. El crecimiento relativo del largo de la quela y el ancho del abdomen respecto del ancho de caparazón mostró la presencia de 2 fases, madura e inmadura, para machos y hembras, respectivamente. La talla en la cual el $50 \%$ de los machos y las hembras alcanzaron la madurez morfométrica fue 13,6 y $8,5 \mathrm{~mm}$, respectivamente. El valor medio del output reproductivo fue de 3,6, la fecundidad relativa de 2041,91, y la talla relativa de madurez sexual fue de 0,4. Como la mayoría de los cangrejos Brachyura, M. bicornutus mostró una fuerte correlación positiva entre la talla de la hembra y la fecundidad. Una comparación entre los parámetros reproductivos descriptos en el presente trabajo y los de las poblaciones de M. bicornutus en Venezuela, Jamaica y Brasil mostró algunas diferencias, por lo tanto, podría sugerirse que las mismas se deberían a efectos latitudinales o ambientales.
\end{abstract}

Palabras clave: Mar Caribe, fecundidad, crecimiento relativo, madurez sexual, cangrejo araña

Abstract.- Size structure within a population, relative growth of secondary sexual characters in both sexes, and fecundity of females were assessed from field samples of Microphrys bicornutus in the vicinity of Bocas del Toro, Caribbean Sea, Panama. The study was based upon 135 individuals captured by hand and a kick net. Carapace width ranged from 6.5 to $14.4 \mathrm{~mm}$ for ovigerous females, 4.2 to $16 \mathrm{~mm}$ for non-ovigerous females, and 5.9 to $17.4 \mathrm{~mm}$ for males. The relative growth of carapace length versus carapace width was isometric in males and negatively allometric in females. Relative growth of the chela length and abdomen width, compared to the carapace width, exhibited 2 phases, immature and mature, for males and females, respectively. The carapace widths at which $50 \%$ of males and females reached morphometric maturity were 13.6 and $8.5 \mathrm{~mm}$, respectively. The mean value of the reproductive output was 3.6, the relative fecundity was 2041.91 eggs, and the relative size at the onset of sexual maturity was 0.4 . As in most brachyuran species, the studied population of $M$. bicornutus showed a strong positive correlation between fecundity and body size. Differences in those parameters for previously studied populations from Venezuela, Jamaica and Brazil may be due to latitudinal or regional environmental effects.

Key words: Caribbean Sea, fecundity, relative growth, sexual maturity, spider crab 


\section{INTRODUCTION}

Comparative studies of population size structure and morphometrics in decapods have become common in recent years, especially due to interest in their variability and its possible relationship to environmental adaptation (Mantelatto et al. 2010). Characteristics such as the size at morphological maturity and reproductive potential are considered powerful tools to access population differences.

Morphometric data such as those based upon relative size of the male chela and female abdomen have been used widely in studies of decapod crustacean relative growth to detect allometric changes reflecting sexual maturity (Hartnoll 1974). Fecundity of females, defined as the number of eggs per batch (clutch) produced by a female, is recognized as a strong indicator of reproductive potential. Both morphological maturity and fecundity of brachyurans from many different habitats and climatic regions have been reported previously (e.g., Hartnoll 1985, Hines 1988, Mantelatto \& Fransozo 1997, Moura \& Coelho 2001, Litulo 2004), and many differences have been reported among conspecific populations. Such differences are usually related to latitudinal temperature gradients (Clarke et al. 1991, Lardies \& Castilla 2001, Wehrtmann \& López 2003, Mantelatto et al. 2010), inter-annual temperature variation (Simons \& Jones 1981, Ouellet \& Plante 2004, Brillon et al. 2005), and regional variation in salinity, food resources, productivity (Bas et al. 2007) or other environmental factors (Mashiko 1990, Hancock et al. 1998, Carmona-Suárez 1992, 2003, 2007).

Microphrys bicornutus (Latreille, 1825) is a spider crab (Majoidea sensu Ng et al. 2008) living on coralline or other shallow subtidal rubble, grass flats, and red mangrove roots (Lemaitre 1981, Keith 1985). The carapace often carries a dense decoration of sponges, anemones, hydroids and algae for concealment (Ghetty \& Hazlett 1978, Williams 1984). It is distributed from North Carolina and Bermuda to Florida, the Gulf of Mexico, Central America, the Antilles, Colombia, Venezuela, and Brazil (Melo 1996, Felder et al. 2009). Population characteristics and ecological features of $M$. bicornutus were studied previously in Venezuela (Buchuaco and Isla Margarita; Carmona-Suárez 1992, 2007, 2013 and López-Greco et al. 2000, respectively), Jamaica (Hartnoll 1965), Grand Cayman Island (Gore et al. 1882), and Brazil (Batista et al. 2009). In the course of these projects investigating inter-population size variations, relative growth, larval histories, and reproductive attributes such as fecundity, differences were reported among populations.
Here we report on a population from Bocas del Toro, on the Caribbean coast of Panama. Despite much of this region holding the status of a preserved area, anthropogenic activities (urbanization and tourismrelated) in the archipelago are increasingly creating an urgent need for information on aquatic biodiversity (Torati et al. 2011). In particular, baseline data such as species lists and insights on reproductive biology are needed for future management and preservation of the region's marine biodiversity.

Given that Microphrys bicornutus has a wide distributional range, it represents an excellent candidate for comparative studies of regional adaptations. We hypothesize that there are differences in the morphometric and reproductive parameters among populations of the same species as regional adaptations. To facilitate latitudinal comparisons, we herewith investigate: [1] population structure, [2] relative growth of secondary sexual characters of both sexes, and [3] fecundity of females for a population from Bocas del Toro, Panama. Our findings are intended to provide a baseline for studies of inter-population variability in a species with a wide geographic range.

\section{MATERIALS AND METHODS}

Crabs were collected by hand from an area encompassing shoreline roots of mangroves (Rizophora) and Thalassia seagrass meadows near the Smithsonian Tropical Research Institute (STRI) marine station (09²0'N, $82^{\circ} 14^{\prime} \mathrm{W}$ ) at Bocas del Toro on the Caribbean coast of Panama in August 2011. This region is located along the northern-most Atlantic side of Panama and comprises large and small islands that provide a number of micro-habitats among mangrove roots, corals, sponges, rubble, and other substrates.

Animals clinging to shoreline mangrove roots were collected by hand while lifting and carefully inspecting roots and associated epifauna, and those from the adjacent grass bed were taken by hand-pushing of a polemounted 22.5 x $45 \mathrm{~cm}$ fine meshed $(1 \mathrm{~mm})$ Wildco ${ }^{\circledR}$ kick net through the grass. This concentrated effort of sampling conducted over a full week (day and night) allowed the capture of diverse sizes of small crabs and full representation of the local population. Due to the limited number of individuals, samples were pooled and no differences between separately sampled biotopes were considered for the data analysis. Individuals were sacrificed by placement into a $-15^{\circ} \mathrm{C}$ freezer for 
approximately $15 \mathrm{~min}$. Sex and the presence of ovigerous females were recorded. Sexes were differentiated depending on the form of the abdomen following the criteria used by Hernández-Reyes et al. (2001) for Mithrax forceps. All measurements were made with digital calipers $\pm 0.01 \mathrm{~mm}$. In both sexes, the carapace length (CL) and width (CW, used as the independent variable or reference measurement in all analyses) were measured. Maximum abdomen width was measured for females (AW, at a level of the fourth abdominal segment) and, chela length (ChL) was measured for males. Quantitative relationships between morphometric data were described by least square regressions $(\mathrm{CL} \times \mathrm{CW}$ for both sexes, $\mathrm{AW} \times \mathrm{CW}$ for females, and $\mathrm{ChL} \times \mathrm{CW}$ for males). Allometric growth of all dimensions relative to $\mathrm{CW}$ was estimated using the allometric equation $\mathrm{Y}=\mathrm{aX}$ (Huxley 1950). These relationships were log-linearized (base 10 ): $\log _{10} \mathrm{ChL} / \mathrm{AW}$ $=\log _{10} \mathrm{a}+\mathrm{b} \log _{10} \mathrm{CW}$, where $\mathrm{b}$ is the regression slope value or allometric coefficient. Allometric coefficients between 0.9 and 1.1 were considered indicative of isometry, lower than 0.9 indicative of negative allometry, and above 1.1 indicative of positive allometry (= ‘conservative definition’ of Clayton 1990). Slope values were compared to the expected isometric values using Student's t-test, at a significance level of $\alpha=0.05$. Slopes and intercepts of different regression lines were compared by ANCOVA covariance analysis (Zar 1999).

External morphological changes mark the end of all the processes that determine maturity in decapods, underpinning criteria commonly used to classify crabs as mature or immature (Somerton 1980, Conan \& Comeau 1986). Estimates of the size at $50 \%$ maturity at the population level $\left(\mathrm{CW}_{50}\right)$ are most frequently used to define the reproductive state in decapods, this being based upon the classification of crabs in a sample into either mature or immature and subsequent estimation of the body size in which $50 \%$ of the specimens are mature. This approach assumes that there is a sigmoidal relation between size and the percentage of mature crabs (Roa et al. 1999). The $\mathrm{CW}_{50}$ may be interpreted as the size at which a randomly chosen specimen has a $50 \%$ chance of being mature (Somerton 1980). Thus, the relative size at which females and males reach morphometric maturity (CW at which $50 \%$ of females and males are morphometrically mature, $\mathrm{CW}_{50}$ ) was calculated using the logistic equation. The logistic function used was $\mathrm{y}=1 /\left(1+\mathrm{e}^{\mathrm{r}\left(\mathrm{CW}-\mathrm{CW}_{50}\right)}\right)$, where $\mathrm{CW}_{50}$ corresponds to the size at which $50 \%$ of the individuals are considered mature and $\mathrm{r}$ stands for the slope of the curve (e.g., Corgos \& Freire 2006, Sal-Moyano et al. 2011).
Ovigerous females were classified according to the stage of development of the eggs, following Mantelatto \& Garcia (1999): Initial Stage - eyes of larvae not visible, eggs mostly filled with yolk and light-red colored; Intermediate Stage - eyes become visible, beginning pigmentation and segmentation of the larvae; Final Stage - zoea becomes visible, dark-brown eggs. Since all females captured had recently deposited eggs and thus belonged to initial stage, they were used for the fecundity analysis. The eggs were carefully removed from the pleopods and counted under a light stereomicroscope. The average volume $\left(\mathrm{mm}^{3}\right)$ of each egg was calculated according to Jones \& Simons (1983) from the formula $1 / 6 \pi I^{3}$, where $I$ is the mean of 2 egg diameters (including the chorionic membrane tightly adhereing to the embryonic surface) for a subsample 15 eggs per female. The minimum and maximum diameters of each egg were measured under a light stereomicroscope. Wet weights of egg masses at all three stages were determined $\pm 1 \mu \mathrm{g}$ using an analytical balance. Eggs from the female were washed in distilled water, after which water was removed by contact with filter paper. Egg masses were first dried until a constant dry weight was reached $\left(50^{\circ} \mathrm{C}\right.$ for $\left.24 \mathrm{~h}\right)$ and then burned for $4 \mathrm{~h}$ at $500^{\circ} \mathrm{C}$ to obtain ash-free weights. Organic material was estimated by subtracting combusted material weight from dry weight. The female's body was treated similarly to their egg mass except that they were both dried and burned as above for 48 and 12 h, respectively (Lardies \& Wehrtmann 1996). The following measurements were taken for each female: body wet weight (BWW), body dry weight (BDW), egg wet weight (EWW), egg dry weight (EDW) and number of eggs (NE). For each female, reproductive output (RO) was calculated as EDW/ BDW x 100 (Clarke et al. 1991), the relative fecundity (RF) was calculated as NE/BDW, and the relative size at the onset of sexual maturity (RSOM, Charnov 1990) was calculated as minimum ovigerous female size/maximum female size. A correlation between the number of eggs and the CW was performed. Voucher specimens were deposited in the Crustacean Collection of the Department of Biology (CCDB), Faculty of Philosophy, Sciences and Letters of Ribeirão Preto, University of São Paulo (FFCLRP/ USP), Brazil and the Department of Biology (ULLZ), University of Louisiana at Lafayette, Lafayette, U.S.A, under catalog numbers CCDB 3557, 3564 and ULLZ 1337613378, 13662.
Vol. 49, № 1, 2014

Revista de Biología Marina y Oceanografía 


\section{RESULTS}

A total of 135 individuals were captured, including 54 (40\%) non-ovigerous females, 18 (13.33\%) ovigerous females, and 63 (46.66\%) males. Non-ovigerous females ranged from 4.2 to $16 \mathrm{~mm} \mathrm{CW}(9.08 \pm 2.3 \mathrm{~mm} \mathrm{CW})$, ovigerous females ranged from 6.5 to $14.4 \mathrm{~mm} \mathrm{CW} \mathrm{(9.93 \pm}$ $2.19 \mathrm{~mm} \mathrm{CW}$ ), and males ranged from 5.9 to $17.4 \mathrm{~mm} \mathrm{CW}$ (10.8 $\pm 3.02 \mathrm{~mm} \mathrm{CW})$ (Fig. 1). Morphometrically, the relative growth of the $\mathrm{CL}$ versus the $\mathrm{CW}$ was isometric in males $\left(\log \mathrm{CL}=0.12+0.99 \log \mathrm{CW}, \mathrm{R}^{2}=0.99, \mathrm{~b}=0.99, \mathrm{t}=\right.$ 153.7, $P<0.0001$ ) and negatively allometric in females $\left(\log \mathrm{CL}=0.42+0.71 \log \mathrm{CW}, \mathrm{R}^{2}=0.1, \mathrm{~b}=0.71, \mathrm{t}=2.93, P\right.$ $<0.01)$.

In males, the relative growth of $\mathrm{ChL}$ with respect to CW differed markedly between immature and mature ones, the immature exhibiting a positively allometric phase (log $\mathrm{ChL}=0.09+1.11 \log \mathrm{CW}, \mathrm{R}^{2}=0.88, \mathrm{~b}=1.11, \mathrm{t}=18.3, P<$ 0.0001 ), and the mature, showing a negatively allometric phase $\left(\log \mathrm{ChL}=0.48+0.68 \log \mathrm{CW}, \mathrm{R}^{2}=0.83, \mathrm{~b}=0.68, \mathrm{t}\right.$ $=8.7, P<0.0001$ ) (Fig. 2). Slopes of the regression lines over these two phases of growth differed significantly (ANCOVA, $\mathrm{F}=9.3, P<0.01$ ). The presence of an inflection point between these phases suggested a pubertal molt.
The analysis of the logistic equation showed that the size at which $50 \%$ of males reached morphometric maturity was $\mathrm{CW}_{50}=13.6 \mathrm{~mm}$. The smallest mature male measured $12.6 \mathrm{~mm} \mathrm{CW}$, and the largest immature male measured $13.8 \mathrm{~mm} \mathrm{CW}$.

In females, relative growth analysis showed that the growth of AW with respect to $\mathrm{CW}$ was negatively allometric in both immature $\left(\log \mathrm{AW}=0.58+0.62 \log \mathrm{CW}, \mathrm{R}^{2}=0.51\right.$, b $=0.62, \mathrm{t}=5.12, P<0.001)$ and mature females $(\log \mathrm{AW}=$ $\left.0.34+0.81 \log \mathrm{CW}, \mathrm{R}^{2}=0.77, \mathrm{~b}=0.81, \mathrm{t}=11.6, P<0.0001\right)$ (Fig. 3). Although the slopes of regressions in this relationship did not differ between the female growth phases, differences in y-intercepts were significant (ANCOVA, $\mathrm{F}=323.7, P<0.001$ ). The analysis of the logistic equation showed that the size at which $50 \%$ of females reached morphometric maturity was $\mathrm{CW}_{50}=8.5 \mathrm{~mm}$. The smallest mature female measured $6.5 \mathrm{~mm} \mathrm{CW}$, and the largest immature female $12.3 \mathrm{~mm} \mathrm{CW}$. In addition, the smallest size ovigerous female captured was $6.5 \mathrm{~mm} \mathrm{CW}$. A wide overlap between CW of large immature females and $\mathrm{CW}$ of those in the mature phase was observed; indicating females of the same carapace width can have undifferentiated or differentiated (mature) abdomens.

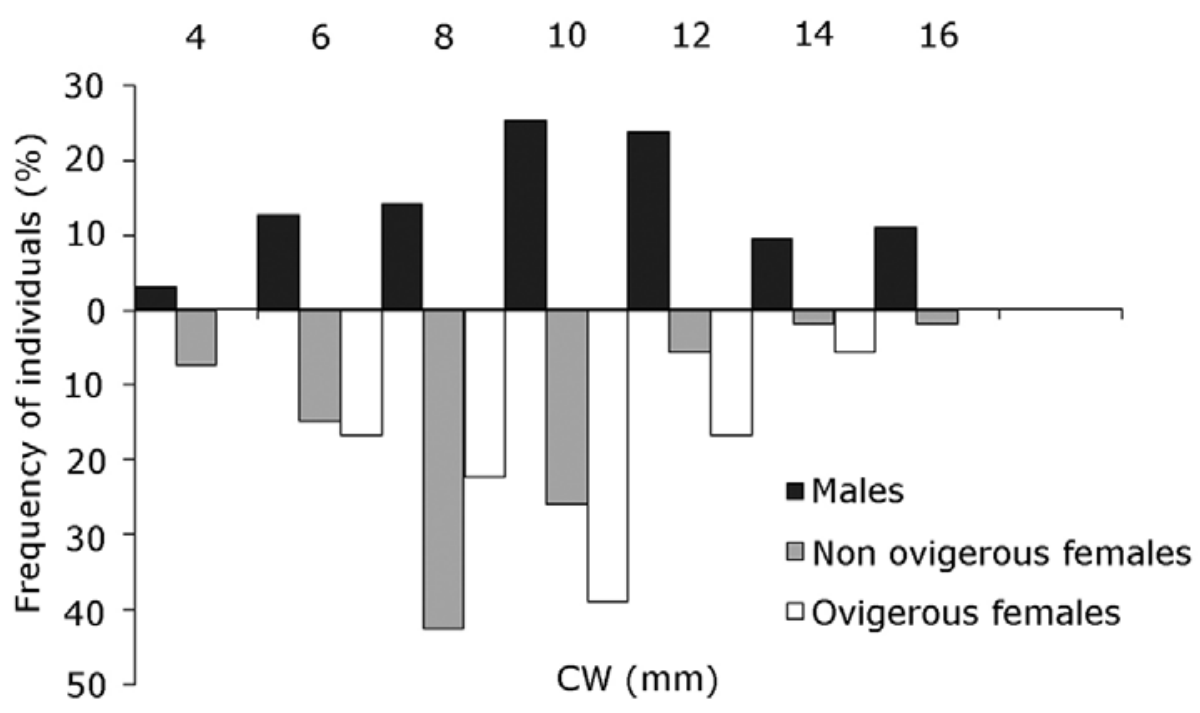

Figure 1. Microphrys bicornutus. Size frequency distributions of ovigerous females, non-ovigerous females and males. Numbers in the upper part of the graph represent the size ranges / Microphrys bicornutus. Distribución de frecuencia de talla de hembras ovígeras, no ovígeras y machos. Los números en la parte superior del gráfico representan los rangos de talla 


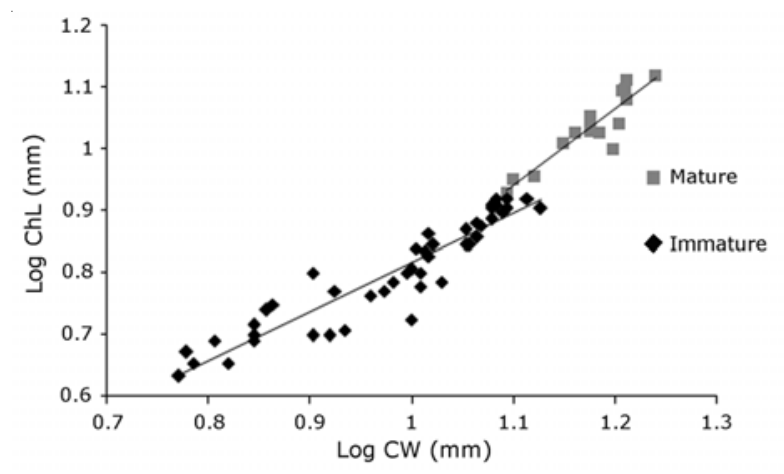

Figure 2. Microphrys bicornutus. Relationships between chela length (ChL) and carapace width (CW) of males; the regression lines correspond to immature and mature males / Microphrys bicornutus. Relaciones entre el largo de la quela (ChL) y el ancho de caparazón (CW) de los machos; las líneas de regresión corresponden a los machos inmaduros y maduros

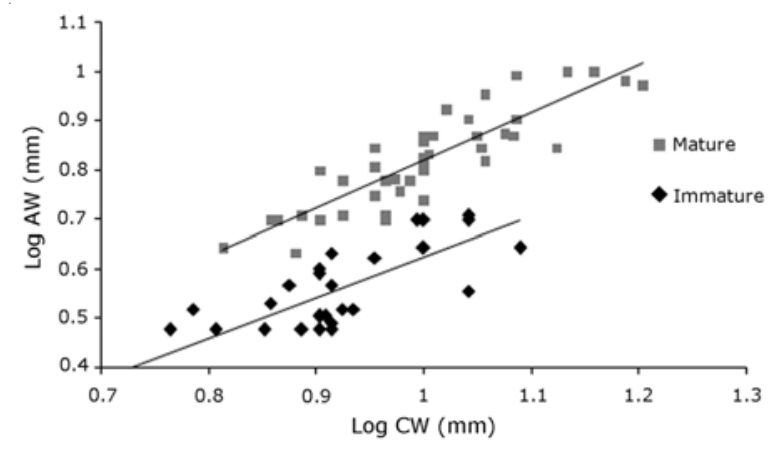

Figure 3. Microphrys bicornutus. Relationships between abdomen width (AW) and carapace width (CW) of females; the regression lines correspond to immature and mature females / Microphrys bicornutus. Relaciones entre el ancho de abdomen (AW) y el ancho de caparazón (CW) de las hembras, las líneas de regresión corresponden a las hembras inmaduras y maduras

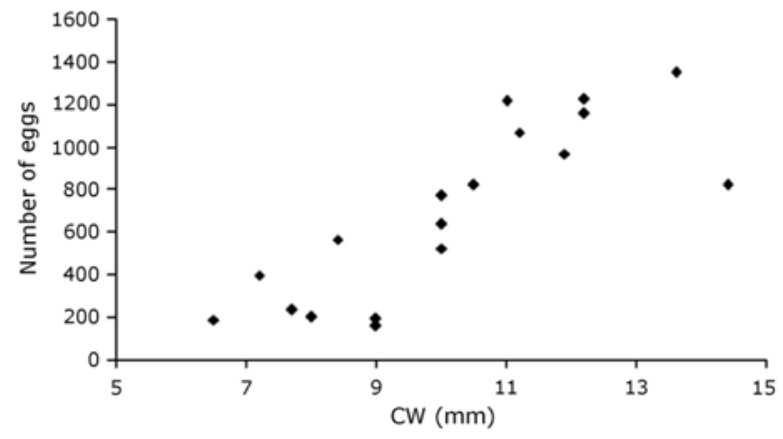

Figure 4. Microphrys bicornutus. Correlation between the number of eggs per batch and the carapace width (CW) in females / Microphrys bicornutus. Correlación entre el número de huevos por puesta y el ancho de caparazón (CW) de las hembras
Table 1. Microphrys bicornutus. Size (carapace width, CW) and weight of ovigerous females. $\mathbf{n}=$ number of females, $\mathbf{s d}=$ standard deviation / Microphrys bicornutus. Talla (ancho de caparazón, CW) y peso de las hembras ovígeras. $\mathrm{n}=$ número de hembras, $\mathrm{sd}=$ desviación estándar

\begin{tabular}{llllc}
\hline $\mathrm{n}=18$ & Mean value & $\mathrm{sd}$ & Minimum & Maximum \\
\hline $\mathrm{CW}(\mathrm{mm})$ & 9.930 & 2.190 & 6.50 & 14.400 \\
Dry weight $(\mathrm{g})$ & 0.2118 & 0.1363 & 0.059 & 0.5495 \\
Water content $(\mathrm{g})$ & 0.2754 & 0.1826 & 0.1067 & 0.7224 \\
Organic matter $(\mathrm{g})$ & 0.094 & 0.053 & 0.031 & 0.205 \\
Ash content $(\mathrm{g})$ & 0.117 & 0.085 & 0.028 & 0.345
\end{tabular}

Mean values of size and weight of ovigerous females were $9.93 \mathrm{~mm} \mathrm{CW}$ and $0.2118 \mathrm{~g}$ dry weight, $0.2754 \mathrm{~g}$ water content, 0.094 g organic matter and $0.117 \mathrm{~g}$ ash content. The standard error, minimum and maximum values of those variables are shown in Table 1 . The mean value/standard error for the egg volume of stage 1 was $0.0253 / 0.0113 \mathrm{~mm}^{3}$. The value of the RO was 3.6/2.02, while the RF was 2041.9/ 1291.7. The RSOM was 0.4 (6.5/16). A significant positive correlation was found between clutch size (number of eggs) in ovigerous females and their $\mathrm{CW}(\mathrm{r}=0.68$, d.f. $=$ 16, $P<0.001, \mathrm{n}=18$, Fig. 4).

\section{Discussion}

In Bocas del Toro, Panama, the majoid crab Microphrys bicornutus reproduces continuously throughout the year, as it does over a large part of its range (Gore et al. 1982). Thus, the present report must be regarded as a restricted initial evaluation of reproductive dynamics in this population. Although the number of ovigerous females captured in the present study is low $(\mathrm{n}=18)$ we consider the results important since they constitute the first reproductive study for this common species in Panamanian waters.

The size frequency distribution reported here showed smaller ranges of female and male sizes than those reported for same species in Buchuaco, which presented ranging from 1.9 to 35.4 mm CL (Carmona-Suárez 2007), and in Isla Margarita, ranging from 4.1 to $33.2 \mathrm{~mm} \mathrm{CL}$ (López-Greco et al. 2000). Hartnoll (1965) also reported that the population from Jamaica $\left(17^{\circ} 43^{\prime} \mathrm{N}, 69^{\circ} 40^{\prime} \mathrm{W}\right)$ consisted of larger sizes, ranging from 11 to $33 \mathrm{~mm}$ of carapace length (extracted from Carmona-Suárez 1992). However, in Brazil, smaller size ranges compared to the ones recorded for Bocas del Toro were found for both sexes, reaching a maximum size of 11 mm (Batista et al. 2009). Size differences for populations of the same species have been most commonly attributed 
to the variation in their latitudinal distribution (e.g., Hines 1989, Conde \& Diaz 1992). Moreover, size differences could also be related to environmental instability with periodic stress in shallow waters at the site [heavy rainfall, terrestrial runoff, and periodic 'natural eutrophication' as reported at Bocas del Toro (Carruthers et al. 2005, D’Croz et al. 2005, Guzman et al. 2005)]. These could favor extinctions of older, larger cohorts, or alter nutritional resources for growth and cause stunting. Specifically in the case of Brazil populations, the smaller size ranges corresponded to immature males and females, and since M. bicornutus lives on the phytal Halimeda opuntia, it was suggested that the complex microhabitat provided by the algae may favor the recruitment of immature crabs (Batista et al. 2009).

In males of several majoid species, relationships between the carapace width and the size of the chelae characterize immature and mature phases, separated by a pubertal molt (Watson 1970, Conan \& Comeau 1986, Schejter \& Spivak 2005, Barón et al. 2009, Sal Moyano et al. 2011). In other cases, they provide evidence of three phases, those being usually labeled as juveniles, adolescents and adults, separated by a pre-pubertal and a pubertal (or terminal) molt respectively (Sainte-Marie et al. 1995, Sampedro et al. 1999, Carmona-Suárez 2003). Here, we report 2 phases, showing the immature phase to end in a discontinuity marking a pubertal molt. These 2 phases were described for the same species from Venezuela, in Buchuaco (Carmona-Suárez 2007) and Isla Margarita (López-Greco et al. 2000), although in the former a small overlap between phases could be distinguished. The estimated size of $50 \%$ morphometric maturity calculated in the present report $(13.6 \mathrm{~mm} \mathrm{CW}$ or 17.4 mm CL) was $13.4 \%$ smaller (a $2.5 \mathrm{~mm}$ difference) than the $19.9 \mathrm{~mm}$ CL calculated by Carmona-Suarez (2007) for the Buchuaco population. However, this value was similar to the one (16.5 $\mathrm{mm} \mathrm{CL}$ ) reported by López-Greco et al. (2000) for the Isla Margarita population. Hence, it is suggested that males from Bocas del Toro and Isla Margarita attain morphometric maturity earlier than males from Buchuaco, showing that the environmental conditions may be acting in a different way in terms of supply for the growth and attainment of maturity in both populations. However, since males from Buchuaco apparently reached larger sizes than those from either Isla Margarita or Bocas del Toro, the acquisition of morphometric maturity at a larger size could also simply suggest that male sizes vary among populations.
In females, similar to other majoid species, the presence of 2 phases was recognized, with separation by a puberty molt (Sainte-Marie \& Hazel 1992, Carmona-Suárez 2003, Schejter \& Spivak 2005, Barón et al. 2009, Sal Moyano et al. 2011). However, in our study, M. bicornutus showed a wide size overlap between immature and mature female phases, similar to that described by Carmona-Suárez (2007) and López-Greco et al. (2000) for the same species from Venezuela. Although the number of individuals used in the present work to calculate morphometric maturity was less than in the aforementioned studies, the estimated size of $50 \%$ morphometric maturity calculated in the present study ( $8.5 \mathrm{~mm} \mathrm{CW}$ or $11.7 \mathrm{~mm} \mathrm{CL}$ ) was similar to the one (12 and $13.6 \mathrm{~mm} \mathrm{CL}$ ) calculated by CarmonaSuárez (2007) and López-Greco et al. (2000). Hence, minimal size difference at morphometric maturity was found between the Bocas del Toro population and those from Buchuaco and Isla Margarita, which likely reflects similar environmental conditions for the growth of these decapods in the Caribbean region. It is noteworthy that males differ in size at morphometric maturity between the Buchuaco and the Bocas del Toro populations, while females do not. It may indicate that females are more conservative in terms of body size, while males are more plastic in responding to varied environmental conditions.

Studies reporting reproductive parameters such as fecundity and/or reproductive output in majoids are scarce considering diversity of this group (Table 2). The mean value of the RF recorded in the present study was similar to that reported for the same species in Venezuela by López-Greco et al. (2000) (2041.9 eggs in present study versus 2391.5), although the mean value of the RO in the present study was less than half the previous report (3.6 in present study versus 8.9). This difference may be caused because of the smaller mean value of egg diameters in stage 1 reported here as compared to that recorded in the aforementioned study. By contrast, in the Buchuaco population, a lower number of eggs was reported (mean = 1067.4), although egg size was larger. Thus, this population may produce less eggs but with higher quantities of yolk (thus, larger size), and thereby yield embryos and larvae optimized to local environmental conditions (CarmonaSuárez 2013). It is known that the RO can vary for a decapod species between Decapod species between different latitudes (Terossi et al. 2010a, b). Similarly, $M$. bicornutus may be responding by having smaller and more numerous eggs in the Bocas del Toro population due to the stress that characterizes this habitat where 
Table 2. Studies conducted on American Majoidea reporting fecundity (mean or maximum and minimum number off eggs) and/ or reproductive output (RO). $\mathrm{CW}=$ carapace width, $\mathrm{CL}=$ carapace length of ovigerous females / Estudios realizados en Majoidea de América reportando la fecundidad (media o máximo y mínimo del número de huevos) y/o el output reproductivo (RO). CW = ancho de caparazón, $\mathrm{CL}$ = largo de caparazón de hembras ovígeras

\begin{tabular}{|c|c|c|c|c|c|}
\hline Species & Study site & Fecundity & RO & Size & References \\
\hline Collodes temuirostris & Mazatlán, México & 1302 & - & 4.9-19.2 mm CW & García- Guerrero \& Hendrickx (2004) \\
\hline Euprognatha bifida & Mazatlán, México & 83 & - & $3.4-8.8 \mathrm{~mm} \mathrm{CW}$ & García- Guerrero \& Hendrickx (2004) \\
\hline Leurocyclus tuberculosus & $\begin{array}{l}\text { Rio de Janeiro, } \\
\text { Brazil }\end{array}$ & 10327.3 & - & 15.3-55.4 mm CW & Stauffer et al. (2011) \\
\hline Libidoclaea granaria & $\begin{array}{l}\text { Atlantic Ocean, } \\
\text { Argentina }\end{array}$ & $1200-9300$ & - & $16-48 \mathrm{~mm} \mathrm{CW}$ & Schejter \& Spivak (2005) \\
\hline Microphrys bicornutus & $\begin{array}{l}\text { Isla Margarita, } \\
\text { Venezuela }\end{array}$ & 2391.5 & 8.90 & $11.2-22.2 \mathrm{~mm} \mathrm{CL}$ & López- Greco et al. (2000) \\
\hline Microphrys bicornutus & $\begin{array}{l}\text { Buchuaco, } \\
\text { Venezuela }\end{array}$ & 1067.4 & - & 7-23.6 mm CL & Carmona- Suárez (2013) \\
\hline Microphrys bicornutus & $\begin{array}{l}\text { Bocas del Toro, } \\
\text { Panamá }\end{array}$ & 2041.9 & 3.60 & $6.5-14.4 \mathrm{~mm} \mathrm{CW}$ & Present study \\
\hline Mithraculus forceps & São Paulo, Brazil & 402.8 & - & $9.4-14.0 \mathrm{~mm} \mathrm{CW}$ & Cobo \& Okamori (2008) \\
\hline Mithrax forceps & $\begin{array}{l}\text { Isla de Margarita, } \\
\text { Venezuela }\end{array}$ & $34-4777$ & - & $11.2-30.3 \mathrm{~mm} \mathrm{CL}$ & Hernández- Reyes et al. (2001) \\
\hline Paradasygyius depressus & Mazatlán, México & 1528 & - & $13.0-31.6 \mathrm{~mm} \mathrm{CW}$ & García- Guerrero \& Hendrickx (2004) \\
\hline Pyromaia tuberculata & Mazatlán, México & 910 & - & $3.8-19.0 \mathrm{~mm} \mathrm{CW}$ & García- Guerrero \& Hendrickx (2004) \\
\hline Stenorhynchus debilis & Mazatlán, México & 1470 & - & $4.8-13.1 \mathrm{~mm} \mathrm{CW}$ & García- Guerrero \& Hendrickx (2004) \\
\hline Stenorhynchus seticornis & São Paulo, Brazil & 621.1 & & $6.0-14.0 \mathrm{~mm} \mathrm{CW}$ & Okamori \& Cobo (2003) \\
\hline Eurypodius latreillii & $\begin{array}{l}\text { Straits of } \\
\text { Magellan, Chile }\end{array}$ & $1627-9384$ & 0.13 & $29-62.9 \mathrm{~mm} \mathrm{CL}$ & Navarrete et al. (1999) \\
\hline Epialtus bituberculatus & $\begin{array}{l}\text { Grande and } \\
\text { Domingas Dias, } \\
\text { Brazil }\end{array}$ & 149 & - & $4.8-7.9 \mathrm{~mm} \mathrm{CW}$ & Cobo \& Barros (2009) \\
\hline Chionoecetes opilio & $\begin{array}{l}\text { Bonne Bay, } \\
\text { Canada }\end{array}$ & $\begin{array}{l}54000 \\
(\max )\end{array}$ & & $37-90 \mathrm{~mm} \mathrm{CW}$ & Comeau et al. (1999) \\
\hline
\end{tabular}

heavy terrestrial runoff and turbidity surges can be frequent. Moreover, it was proposed that for the majoid crab, Mithraculus forceps (A. Milne-Edwards, 1875), certain environmental conditions, such as the availability of food for adults, may have some effect on intra-specific differences related to the values of the RO of this crab (Cobo \& Okamori 2008). In the case of the RSOM, a similar value was found to that reported by López-Greco et al. (2000), also coinciding with values earlier reported for several other brachyurans, particularly majoid crabs (Hines 1982). The positive correlation between the CW and the number of eggs reported here for Microphrys bicornutus is a trend commonly evident in most brachyurans (e.g., Hines 1982, García-Guerrero \& Hendrickx 2004).
The present study, in combination with comparative data available in the literature, shows a relatively variable pattern in fecundity among majoids. Reproductive adaptation may depend on divergent strategies in terms of reproductive performance and output, these perhaps being in turn related to variable patterns in population structures, sizes at maturation, seasonality, sex ratios and other factors bearing on reproduction. Thus, more thorough study of these topics for related species and regional populations of majoids is required, both for appreciation of phylogenetic diversity and understanding of environmental constraints that likely bear on majoid reproductive adaptation. 


\section{AcKnowledgments}

The authors express their deep gratitude to Smithsonian Tropical Research Institute (STRI) in Panamá for a fellowship enabling to travel to Panamá and facilities during the development of the course on Crustacean biology and taxonomy, and for assistantance in obtaining collecting permits. Special thanks are due to Rachel Collin (STRI), who secured funding for this course and assisted with logistics, and to Jenny Felder for her enthusiastic help during both field and lab activities. All authors thank students, assistants and STRI staff involved in the course hosted at STRI's Bocas del Toro Research Station from July 31 to August 15, 2011. We also thank Tomas Luppi, Nahuel Farias and Andrea Gavio for their help with the statistical analyses, and anonymous reviewers for suggestions and contributions toward improving this article. For DLF this is University of Louisiana Laboratory for Crustacean Research contribution number 168.

\section{LITERATURE CITED}

Barón PJ, AP Quiroga, GA Leal \& X González-Pisani. 2009. Morphological maturity of the knobbed spider crab, Leurocyclus tuberculosus (H. Milne Edwards \& Lucas, 1842) (Brachyura: Majidae) in the Northern Patagonian Gulfs. Crustaceana 82: 267-273.

Bas C, E Spivak \& KAnger. 2007. Seasonal and interpopulational variability in fecundity, egg size, and elemental composition (CHN) of eggs and larvae in a grapsoid crab, Chasmagnathus granulatus. Helgoland Marine Research 61: 225-237.

Batista JB, RMV Leonel \& MAJ Costa. 2009. Características populacionais de Microphrys bicornutus (Brachyura, Mithracidae) no fital de Halimeda opuntia (Chlorophyta, Halimedaceae), em área recifal submetida á visitação humana, em João Pessoa, Paraíba. Iheringia, Série Zoologia 99: 44-52.

Brillon S, Y Lambert \& J Dodson. 2005. Egg survival, embryonic development, and larval characteristics of northern shrimp (Pandalus borealis) females subject to different temperature and feeding conditions. Marine Biology 147: 895-911.

Carmona-Suárez CA. 1992. Interpopulation size variation in a tropical decorator crab, Microphrys bicornutus (Latreille, 1825) (Decapoda, Brachyura, Majidae). Crustaceana 63: 319-322.

Carmona-Suárez CA. 2003. Reproductive biology and relative growth in the spider crab Maja crispata (Crustacea: Brachyura: Majidae). Scientia Marina 67: 75-80.

Carmona-Suárez CA. 2007. Spatial distribution density, and relative growth of Microphrys bicornutus (Latreille, 1826) (Brachyura: Majidae) in five biotopes in a Thalassia complex. Scientia Marina 71: 5-14.
Carmona-Suárez CA. 2013. Population dynamics and reproductive aspects of the decorator crab Microphrys bicornutus (Crustacea: Brachyura: Majidae) in an extreme shallow Thalassia complex. Journal of the Marine Biological Association of the United Kingdom 93: 725-731.

Carruthers TJB, PAG Barnes, GE Jacome \& JW Fourqurean. 2005. Lagoon scale processes in a coastally influenced Caribbean system: Implications for the seagrass Thalassia testudinum. Caribbean Journal of Science 41: 441455.

Charnov EL. 1990. Relative size at the onset of sexual maturity (RSOM) is an interesting number in crustacean growth (Decapoda, Pandalidae). Crustaceana 59: 108-109.

Clarke A, CCE Hopkins \& EM Nilssen. 1991. Egg size and reproductive output in the deep-water prawn Pandalus borealis (Kroyer, 1838). Functional Ecology 5: 724-730.

Clayton DA. 1990. Crustacean allometric growth: a case for caution. Crustaceana 60: 270-290.

Cobo VJ \& CM Okamori. 2008. Fecundity of the spider crab Mithraculus forceps (Decapoda, Mithracidae) from the northeastern coast of the state of São Paulo, Brazil. Iheringia, Série Zoologia 98: 84-87.

Cobo VJ \& SDP Barros. 2009. Reproductive output of the spider crab Epialtus bituberculatus (H. Milne Edwards, 1834) (Crustacea, Decapoda, Brachyura) associated with beds of the alga Sargassum cymosum (C. Agardh, 1820) on the southeastern Brazilian coast. Invertebrate Reproduction and Development 53: 53-58.

Comeau M. M Starr, GY Conan, G Robichaud \& JC Therriault. 1999. Fecundity and duration of egg incubation for multiparous female snow crabs (Chionoecetes opilio) in the fjord of Bonne Bay, Newfoundland. Canadian Journal of Fisheries and Aquatic Sciences 56: 1088-1095.

Conan GY \& M Comeau. 1986. Functional maturity and terminal molt of the male snow crab, Chionoecetes opilio. Canadian Journal of Fisheries and Aquatic Science 43: 1710-1719.

Conde JE \& H Diaz. 1992. Extension of the stunting range in ovigerous females of the mangrove crab Aratus pisonii $(\mathrm{H}$. Milne Edwards, 1837) (Decapoda, Brachyura, Grapsidae). Crustaceana 62: 319-322.

Corgos A \& J Freire. 2006. Morphometric and gonad maturity in the spider crab Maja brachydactyla: a comparison of methods for estimating size at maturity in species with determinate growth. Journal of Marine Science 63: 851-859.

D’Croz L, JB Del Rosario \& P Góndola. 2005. The effect of fresh water runoff on the distribution of dissolved inorganic nutrients and plankton in the Bocas del Toro Archipelago, Caribbean Panama. Caribbean Journal of Science 41: 414-429.

Felder DL, F Álvarez, JW Goy \& R Lemaitre. 2009. Decapoda (Crustacea) of the Gulf of Mexico, with comments on the Amphionidacea. In: Felder DL \& DK Camp (eds). Gulf of Mexico Origin, Waters, and Biota, pp. 1019-1104. Texas A \& M University Press, College Station. 
García-Guerrero M \& ME Hendrickx. 2004. Fecundity traits of seven species of brachyuran crabs (Decapoda: Brachyura) from the Pacific coast of Mexico. Contributions to the Study of East Pacific Crustaceans 3: 79-87.

Getty T \& BA Hazlett. 1978. Decoration behaviour in Microphrys bicornutus (Latreille, 1825) (Decapoda, Brachyura). Crustaceana 34: 105-108.

Gore RH, LE Scotto \& LJ Becker. 1982. Community composition, stability, and trophic partitioning in decapod crustaceans inhabiting some subtropical sabellariid worm reefs. Bulletin of Marine Science 28: 221-248.

Guzman HM, PAG Barnes, CE Lovelock \& IC Feller. 2005. A Site Description of the CARICOMP mangrove, seagrass and coral reef Sites in Bocas del Toro, Panama. Caribbean Journal of Science 41: 430-440.

Hancock M, J Hughes \& S Bunn. 1998. Influence of genetic and environmental factors on egg and clutch sizes among populations of Paratya australiensis Kemp (Decapoda: Atyidae) in upland rainforest streams, south-east Queensland. Oecologia 115: 483-491.

Hartnoll RG. 1965. The biology of spider crabs: a comparison of British and Jamaican species. Crustaceana 9: 1-16.

Hartnoll RG. 1974. Variation in growth pattern between some secondary sexual characters in crabs (Decapoda: Brachyura). Crustaceana 27: 131-136.

Hartnoll RG. 1985. Growth, sexual maturity and reproductive output. Crustaceans Issues 3: 101-128.

Hernández-Reyes IM, JL Palazón-Fernández, JA BolañosCurvelo \& JE Hernández. 2001. Reproductive biology of Mithrax forceps (A. Milne-Edwards, 1875) (Crustacea: Decapoda: Majidae). Ciencias Marinas 27: 21-34.

Hines AH. 1982. Allometric constrains and variables of reproductive effort in brachyuran crabs. Marine Biology 69: 309-320.

Hines AH. 1988. Fecundity and reproductive output in two species of deep-sea crabs, Geryon fenneri and $G$. quinquedens (Decapoda: Brachyura). Journal of Crustacean Biology 8: 557-562.

Hines AH. 1989. Geographic variations in size at maturity in brachyuran crabs. Bulletin of Marine Science 45: 356-368.

Huxley JS. 1950. Relative growth and form transformation. Proceedings of the Royal Society of London (B) 137: 465-469.

Jones MB \& MJ Simons. 1983. Latitudinal variation in reproductive characteristics of a mud crab, Helice crassa (Grapsidae). Bulletin of Marine Science 33: 656-670.

Keith DE. 1985. Shallow-water and terrestrial brachyuran crabs of Roatan and The Swan Islands, Honduras. Sarsia 70: 251-278.

Lardies M \& JC Castilla. 2001. Latitudinal variation in the reproductive biology of the commensal crab Pinnaxodes chilensis (Decapoda: Pinnotheridae) along the Chilean coast. Marine Biology 139: 1125-1133.
Lardies M \& I Wehrtmann. 1996. Aspects of the reproductive biology of Petrolisthes laevigatus (Guérin, 1835) (Decapoda, Anomura, Porcellanidae). Part I: Reproductive output and chemical composition of eggs during embryonic development. Archive of Fishery and Marine Research 43: 121-135.

Lemaitre R. 1981. Shallow-water crabs (Decapoda, Brachyura) collected in the southern Caribbean near Cartagena, Colombia. Bulletin of Marine Science 31: 234-266.

Litulo C. 2004. Reproductive aspects of a tropical population of the fiddler crab Uca annulipes (H. Milne Edwards, 1837) (Brachyura: Ocypodidae) at Costa do Sol Mangrove, Maputo Bay, southern Mozambique. Hydrobiologia 525: 167-173.

López-Greco LS, JE Hernandez, J Bolanos, EM Rodriguez \& G Hernandez. 2000. Population features of Microphrys bicornutus Latreille, 1825 (Brachyura, Majidae) from Isla Margarita, Venezuela. Hydrobiologia 439: 151-159.

Mantelatto FL \& A Fransozo. 1997. Fecundity of the crab Callinectes ornatus Ordway, 1863 (Decapoda, Brachyura, Portunidae) from Ubatuba region, São Paulo, Brazil. Crustaceana 70: 214-226.

Mantelatto FL \& RB Garcia. 1999. Reproductive potential of the hermit crab Calcinus tibicen (Crustacea, Anomura) from Ubatuba, São Paulo, Brazil. Journal of Crustacean Biology 19: 268-275.

Mantelatto FL, LC Fernandes-Góes, MZ Fantucci, R Biagi, LM Pardo \& JM Góes. 2010. A comparative study of population traits between two South American populations of the striped-legged hermit crab Clibanarius vittatus. Acta Oecologica 36: 1-15.

Mashiko K. 1990. Diversified egg and clutch sizes among local populations of the freshwater prawn Macrobrachium nipponense. Journal of Crustacean Biology 10: 306-314.

Melo GAS. 1996. Manual de identificação dos Brachyura (caranguejos e siris) do litoral brasileiro, 603 pp. Editora Plêiade, São Paulo.

Moura N \& PA Coelho. 2001. Fecundidade de Goniopsis cruentata (Latreille, 1803) no manguezal do rio Paripe, Pernambuco, Brasil. Tropical Oceanography 29: 75-80.

Navarrete N, R Soto, E Quiroga, M Vargas \& IS Wehrtmann. 1999. Egg production in Eurypodius latreillii Guérin, 1828 (Decapoda: Majidae) in the Straits of Magellan, southern Chile. Scientia Marina 63: 333-337.

Ng PKL, D Guinot \& PJL Davie. 2008. Systema Brachyrorum: Part 1. An annotated checklist of extant brachyuran crabs of the world. Raffles Bulletin of Zoology 17: 1-286.

Okamori CM \& VJ Cobo. 2003. Fecundity of the arrow crab Stenorhynchus seticornis in the southern Brazilian coast. Journal of the Marine Biological Association of the United Kingdom 83: 979-980. 
Ouellet P \& F Plante. 2004. An investigation of the sources of variability in American lobster eggs and larvae size: Maternal effects, and inter-annual and inter-regional comparisons. Journal of Crustacean Biology 24: 481-495.

Roa R, B Ernst \& F Tapia. 1999. Estimation of size at sexual maturity: an evaluation of analytical and resampling procedures. Fishery Bulletin 97: 570-580.

Sainte-Marie B \& F Hazel. 1992. Molting and mating of snow crabs, Chionoecetes opilio (O. Fabricus), in shallow waters of the northwestern Gulf of Saint Lawrence. Canadian Journal of Fisheries and Aquatic Science 49: 12821293.

Sainte-Marie B, S Raymond \& JC Brèthes. 1995. Growth and maturation of the benthic phases of male show crab, Chionoecetes opilio (Brachyura: Majidae). Canadian Journal of Fisheries and Aquatic Science 52: 903-924.

Sal-Moyano MP, MA Gavio \& MD Maggi. 2011. Morphometric and gonad maturity of the spider crab Libinia spinosa (Crustacea: Brachyura: Majoidea: Epialtidae) in Argentina. Journal of the Marine and Biological Association of the United Kingdom 91: 837-844.

Sampedro MP, E Gonzalez-Gurriarán, J Freire \& $\mathbf{R}$ Muino. 1999. Morphometry and sexual maturity in the spider crab Maja squinado (Decapoda: Majidae) in Galicia, Spain. Journal of Crustacean Biology 9: 578-592.

Schejter L \& E Spivak. 2005. Morphometry, sexual maturity, fecundity and epibiosis of the South American spider crab Libidoclea granaria (Brachyura: Majidae). Journal of the Marine and Biological Association of the United Kingdom 85: 857-863.

Simons M \& MB Jones. 1981. Populations and reproductive biology of the mud crab Macrophtalmus hirtipes (Jacquinot, 1853) (Ocypodidae), from marine and estuarine habitats. Journal of Natural History 15: 981-994.
Somerton DA. 1980. A computer technique for estimating the size of sexual maturity in crabs. Canadian Journal of Fishery and Aquatic Science 37: 1488-1494.

Stauffer T, MC Ostrovski, TCG Silva-Ferreira \& T Costa. 2011. Biology of the crab Leurocyclus tuberculosus $(\mathrm{H}$. Milne Edwards \& Lucas, 1843) by catch from pink shrimp trawl fishery in the coast of Rio de Janeiro, Brazil. Nauplius 19: 55-61.

Terossi M, LS Torati, I Miranda, MA Scelzo \& FL Mantelatto. 2010a. Comparative reproductive biology of two southwestern Atlantic populations of the hermit crab Pagurus exilis (Crustacea: Anomura: Paguridae). Marine Ecology 31: 584-591.

Terossi M, IS Wehrtmann \& FL Mantelatto. 2010b. Interpopulation comparison of reproduction of the Atlantic shrimp Hippolyte obliquimanus (Caridea: Hippolytidae). Journal of Crustacean Biology 30: 571-579.

Torati LS, S De Grave, TJ Page \& A Anker. 2011. Atyidae and Palaemonidae (Crustacea: Decapoda: Caridea) of Bocas del Toro, Panama. Check List 7: 798-805.

Watson J. 1970. Mating behaviour in the spider crab Chionoecetes opilio. Journal of the Fisheries Research Board of Canada 29: 447-449.

Wehrtmann IS \& G López. 2003. Effects of temperature on the embryonic development and hatchling size of Betaeus emarginatus (Decapoda: Caridea: Alpheidae). Journal of Natural History 37: 2165-2178.

Williams AB. 1984. Shrimps, lobsters and crabs of the Atlantic coast of the eastern United States, Maine to Florida, 550 pp. Smithsonian Institution Press, Washington.

Zar JH. 1999. Biostatistical analysis, 663 pp. Prentice Hall, Englewood Cliffs.

Received 20 March 2013 and accepted 24 January 2014

Editor: Claudia Bustos 